\title{
HUBUNGAN SELF EFFICACY, MOTIVASI BERPRESTASI, PROKRASTINASI AKADEMIK DAN STRES AKADEMIK MAHASISWA
}

\author{
Dony Darma Sagita \\ Universitas Negeri Padang \\ Daharnis \\ Universitas Negeri Padang \\ Syahniar \\ Universitas Negeri Padang
}

\begin{abstract}
Abstrak
Penelitian ini dimotivasi oleh stres yang menjadi masalah yang kompleks bagi siswa dalam kehidupan sehari-hari. Self efficacy, motivasi berprestasi, dan penundaan akademik diharapkan dapat mempengaruhi stres akademis siswa. Tujuan penelitian ini adalah untuk mendeskripsikan: (1) self efficacy, (2) motivasi berprestasi, (3) penundaan akademik, (4) stres akademik siswa, (5) korelasi self efficacy dengan stres akademik siswa, (6) korelasi prestasi motivasi dengan tekanan akademik siswa, (7) korelasi penundaan akademik dengan tekanan akademis siswa, dan (8) korelasi self efficacy, motivasi berprestasi dan penundaan akademik dengan tekanan akademik siswa.

Penelitian ini menggunakan pendekatan kuantitatif dengan metode deskriptif korelasi dan populasi adalah siswa Program Bimbingan dan Konseling Fakultas Pendidikan Universitas Negeri Padang. Teknik samplingnya adalah proportional stratified random sampling. Instrumen itu adalah model skala Likert. Instrumen reliabilitas self efficacy sebesar 0,930, motivasi berprestasi sebesar 0,906, penundaan akademik sebesar 0,868, dan tekanan akademik siswa sebesar 0,932. Validitas instrumen self efficacy 0,554, motivasi berprestasi adalah 0,469 , penundaan akademik adalah 0,453 , dan tekanan akademik siswa adalah 0,568. Data dianalisis dengan menggunakan regresi linier sederhana dan regresi berganda.

Hasil penelitian menunjukkan bahwa: (1) motivasi diri dan motivasi berprestasi siswa berada pada kategori tinggi, (2) penundaan akademik dan tekanan akademik siswa berada pada kategori sedang, (3) terdapat korelasi negatif dan signifikan antara self efficacy dengan tingkat kemahasiswaan. stres akademik, (4) ada hubungan negatif dan signifikan antara motivasi berprestasi dengan stres akademik siswa, (5) terdapat hubungan positif dan signifikan antara penundaan akademik dengan tekanan akademik siswa, (6) terdapat hubungan yang signifikan antara self efficacy, motivasi berprestasi dan penundaan akademik dengan stres akademis siswa bersama-sama, dan (7) implikasinya adalah masukan dari berbagai pihak yang terlibat untuk meningkatkan self efficacy dan motivasi berprestasi siswa dan mengurangi atau mencegah penundaan dan tekanan akademis.
\end{abstract}

Kata kunci: Self Efficacy, Motivasi Berprestasi, Penundaan Akademik, Tekanan Akademik.

\section{Abstract}

This research is motivated by the stress that become a complex problem for students in daily life. Self efficacy, achievement motivation, and academic procrastination expect to affect student's academic stress. The research purpose was to describe: (1) self efficacy, (2) achievement motivation, (3) academic procrastination, (4) student academic stress, (5) correlation of self efficacy with student's academic stress, (6) correlation of achievement motivation with student's academic stress, (7) correlation of academic procrastination with student's academic stress, and (8) correlation of self efficacy, achievement motivation and academic procrastination with student's academic stress.

This study used quantitative approach with correlation descriptive method and the population were students of Guidance and Counseling Program of Education Faculty State University of Padang. The sampling technique was proportional stratified random sampling. The instrument was a scale model of Likert. The instrument reliability of self efficacy was 0,930, achievement motivation was 0,906 , academic procrastination was 0,868 , and student's academic stress was 0,932 . The instrument validity of self efficacy 0,554 , achievement motivation was 0,469 , academic procrastination was 0,453 , and student's academic stress was 0,568. Data were analyzed by using simple linier regression and multiple regression.

The result indicates that: (1) self efficacy and achievement motivation of students are at the high category, (2) academic procrastination and student's academic stress are in the moderate category, (3) there are negative correlation and significant between self efficacy with student's academic stress, (4) there are negative and significant correlation between achievement motivation and student's academic stress, (5) there are positive and significant correlation between academic procrastination with student's academic 
stress, (6) there are significant correlation between self efficacy, achievement motivation and academic procrastination with student's academic stress together, and (7) the implication are inputs from the various parties involved in to increase self efficacy and achievement motivation of students and reduce or prevent procrastination and academic stress..

Keywords: Self Efficacy, Achievement Motivation, Procrastination Academic, Academic Stress

\section{PENDAHULUAN}

Mahasiswa merupakan kelompok generasi muda yang sedang belajar atau sedang menuntut ilmu di perguruan tinggi. Aktivitas dan tugas mahasiswa sebagai seorang peserta didik adalah belajar yaitu belajar ilmu pengetahuan, berorganisasi, bermasyarakat serta belajar menjadi pemimpin untuk mencapai kesuksesan dalam hidupnya. Menurut As'ari (2007:14) mahasiswa sering disebut sebagai kelompok cendikiawan dan golongan intelektual yang memegang beban berat di pundak untuk menetukan nasib masa depan bangsa.

Mahasiswa dengan kapasitasnya yang lebih tinggi diharapkan mampu memahami konsep, dapat memetakan permasalahan dan memilih solusi yang terbaik untuk permasalahan tersebut. Namun, berbagai permasalahan bisa saja timbul dalam diri seorang mahasiswa dalam pelaksanaan aktivitas akademiknya, banyaknya kegiatan yang harus dikerjakan dan dilaksanakan, banyaknya tuntutan yang harus dipenuhi, manajemen waktu yang tidak bagus, dan tugas kuliah menumpuk. Kondisi seperti ini menurut Sarafino (2006:61) diprediksi dapat memicu stres pada mahasiswa apabila dia tidak mampu memenuhi tuntutan-tuntutan tersebut.

Stres telah menjadi masalah nyata dalam kehidupan sehari-hari manusia. Sarafino (2006:62) mendefinisikan stres sebagai suatu kondisi yang disebabkan karena ketidaksesuaiannya antara situasi yang diinginkan dengan keadaan biologis, psikologis atau sistem sosial individu tersebut. Lebih lanjut, Sarafino (2006:65) mengemukakan stres yang dihadapi individu itu bermacam-macam dan berbeda antar satu individu dengan individu lainnya. Hal ini disebabkan oleh berbagai faktor seperti motivasi, kepribadian, dan intelektual yang terdapat dalam diri individu tersebut.

1. Dalam bidang akademik, tekanan, dan tuntutan yang bersumber dalam kegiatan akademik disebut stres akademik.( Taufik, T., \& Ifdil, I., 2013). Stres akademik telah menjadi permasalahan yang kompleks bagi mahasiswa. Berbagai tuntutan yang harus dilakukan sebagai seorang mahasiswa baik yang berasal dari internal maupun eksternal. Carveth, dkk (dalam Misra dan McKean, 2000) mengemukakan bahwa stres akademik juga meliputi persepsi mahasiswa terhadap banyaknya pengetahuan yang harus dikuasai dan persepsi terhadap kecukupan waktu untuk mengembangkannya. Lebih lanjut, Oon (2007:34) mengungkapkan stres akademik yang dialami mahasiswa terus menerus akan menimbulkan penurunan daya tahan tubuh mahasiswa sehingga mudah mengalami sakit dan penurunan daya tubuh. Hal ini juga berdampak kepada psikologis mahasiswa yang meliputi rasa percaya diri dan emosi yang tidak terkontrol dengan baik.

2. Hasil penelitian Liu (2011) kepada 368 siswa sekolah Cina didapatkan hasil 90\% siswa mengalami stres akademik yang disebabkan oleh ujian, kurangnya prestasi di sekolah, penundaan tugas, pekerjaan rumah, iklim sekolah yang kurang mendukung (guru, teman kelas), keyakinan dan kemauan belajar, serta ketatnya peraturan di sekolah. Berbagai faktor yang menjadi penyebab terjadinya stres akademik pada mahasiswa seperti yang dikemukakan Olejnik dan Holscuch (dalam Eriyanti, 2012:4) yaitu ujian, keterampilan belajar, penundaan (procrastination), dan standar akademik yang tinggi. Faktor lain yang menjadi penyebab stres akademik pada mahasiswa adalah pola pikir, kepribadian, keyakinan diri, jam pelajaran yang padat, tekanan berprestasi, dan dorongan orangtua (Oon, 2007:36).

3. Mahasiswa yang mengalami stres akademik cenderung dipengaruhi oleh keterampilan dalam manajemen waktu antara belajar dan kegiatan lainnya. Rizki (2009:15) mengungkapkan banyak mahasiswa yang mengeluh karena tidak dapat membagi waktu kapan harus memulai dan mengerjakan sesuatu sehingga waktu yang seharusnya dapat bermanfaat menjadi terbuang dengan percuma. Rumiani (2006:38) menyatakan kecenderungan untuk menunda dalam melaksanakan suatu aktivitas disebut dengan prokrastinasi.

Burka dan Yuen (dalam Ilfiandra, 2012:3) mengemukakan prokrastinasi itu adalah, "To defer action: to put of till another day or time”. Maksud dari pernyataan tersebut ialah prokrastinasi merupakan suatu kegiatan menunda tindakan dalam melakukan suatu aktivitas dari suatu waktu ke waktu yang lainnya.

Dalam kaitannya dengan lingkup akademik, prokrastinasi dijelaskan sebagai perilaku menunda tugas-tugas akademis sampai batas akhir waktu yang tersedia. Penundaan penyelesaian tugas akademik ini disebut dengan prokrastinasi akademik (Rumiani, 2006:38). Hal ini didukung oleh Solomon dan Rothblum (dalam Rizki, 2009:28) yang menjelaskan bahwa, "The prevalence of procrastination in six areas of academic functioning: (a) writing a term paper, (b)studying for an exam, (c) keeping up with weekly reading assignments, (d) performing administrative task, (e) attending meetings, and $(f)$ performing academic task in general". Terdapat enam area akademik untuk melihat jenis-jenis tugas yang lazim 
diprokrastinasi oleh mahasiswa, yaitu tugas menulis, tugas belajar menghadapi ujian, tugas membaca, tugas administratif, tugas kehadiran, dan tugas akademik secara keseluruhan.

William (dalam Tatan, 2012:864) dalam penelitiannya mengemukakan bahwa $90 \%$ mahasiswa dari perguruan tinggi telah menjadi seorang prokrastinator, $25 \%$ adalah orang yang suka menunda-nunda kronis dan mereka pada umumnya berakhir mundur dari perguruan tinggi. Jadi persentase mahasiswa dalam prokrastinasi sangat tinggi. Jumlah ini akan meningkat seiring dengan lama masa studi mahasiswa tersebut. Selain itu, hasil penelitian Patricia (2012) menunjukkan bahwa terdapat korelasi positif antara prokrastinasi dengan stres akademik mahasiswa. Berdasarkan penjelasan sebelumnya dapat disimpulkan bahwa semakin tinggi prokrastinasi akademik mahasiswa maka semakin tinggi stres akademik mahasiswa dan semakin rendah prokrastinasi akademik maka semakin rendah juga stres akademik mahasiswa.

2. Faktor lain yang dapat menyebabkan stres akademik pada mahasiswa adalah keyakinan (efficacy). Keyakinan akan kemampuan diri dalam menyelesaikan tugas akademik dapat meningkatkan usaha untuk mencapai tujuan, namun juga dapat menjadi penghambat dalam mencapai sasaran.

Bandura dan Woods (dalam untung, 2008:27) menjelaskan bahwa efikasi diri mengacu pada kemampuan individu untuk meningkatkan motivasi, kemampuan kognitif, dan tindakan yang diperlukan dalam menanggapi berbagai situasi yang dihadapinya. Keyakinan yang ada dalam diri individu diharapkan mampu membantu mahasiswa dalam menghadapi berbagai situasi yang terjadi dalam dirinya. Bandura (dalam Sarafino, 2006:94) mengemukakan self efficacy yang dimiliki individu dapat membuat individu mampu menghadapi berbagai situasi. Hal ini sesuai dengan yang dikemukakan Sarafino (2006:94) yang mengatakan bahwa individu yang memiliki self efficacy yang tinggi akan mengalami tekanan yang lebih rendah ketika berhadapan dengan sumber stres atau stresor.

Seterusnya, faktor lain yang dapat menimbulkan stres akademik pada mahasiswa adalah motivasi berprestasi. Motivasi berprestasi menuntut individu untuk meningkatkan kemampuan yang dimiliki secara penuh untuk mendapatkan hasil yang terbaik. Hal itu diperjelas oleh Hasibuan (2005:112) bahwa motivasi berprestasi adalah dorongan seseorang untuk mengembangkan kreativitas dan mengarahkan semua kemampuan serta energi yang dimiliki demi mencapai prestasi belajar yang optimal. Selanjutnya, Hasibuan (2005:114) berpendapat bahwa bentuk motivasi berprestasi pada mahasiswa dapat berupa kemampuannya dalam meningkatkan prestasi belajar, kemampuan mengatasi segala hambatan dalam belajar, memelihara kualitas belajar, kompetensi dalam meraih prestasi yang lebih tinggi lagi, mencari penyelesaian dalam permasalahan dalam pengerjaan tugas, malu terhadap kegagalan, dan berusaha menghindari kegagalan dengan prestasi.
Motivasi berprestasi menuntut individu untuk meningkatkan kemampuan yang dimiliki secara penuh untuk mendapatkan hasil yang terbaik. Mendukung pendapat Hasibuan di atas, Naurilita (2012) dengan penelitiannya tentang"Hubungan penyesuaian diri, motivasi berprestasi dengan stres akademik mahasiswa perantauan Bandung" menjelaskan bahwa, terdapat hubungan negatif antara motivasi berprestasi dengan stres akademik mahasiswa dengan sumbangan sebesar 28,6\%.

Berdasarkan penjelasan di atas, dapat disimpulkan bahwa stres akademik dapat menjadi suatu permasalahan yang kompleks bagi mahasiswa terutama dalam pelaksanaan kehidupan efektif sehari-harinya. Oleh karena itu, bimbingan dan konseling memiliki peranan yang penting dalam usaha membantu mahasiswa dalam mengentaskan permasalahan tersebut.

\section{METODOLOGI}

Penelitian ini menggunakan pendekatan kuantitatif dengan jenis deskriptif korelasional. Populasi penelitian adalah mahasiswa BK FIP UNP yang terdaftar pada tahun ajaran 2014/2015 sebanyak 575 orang mahasiswa. Sampel dalam penelitian ini sebanyak 236 siswa. Penarikan sampel menggunakan teknik Propotional Stratified Random Sampling. Instrumen yang digunakan pada penelitian ini berupa Skala Likert. Analisis data dibantu dengan menggunakan program SPSS. Hasil uji reliabilitas instrumen self efficacy sebesar 0.930, motivasi berprestasi sebesar 0.906, prokrastinasi akademik sebesar 0.868, dan stres akademik sebesar 0.932 . Hasil validitas self efficacy sebesar 0.554, motivasi berprestasi sebesar 0.469, prokrastinasi akademik sebesar 0.453 , dan stres akademik sebesar 0.568. Data penelitian dianalisis menggunakan regresi linier sederhana dan regresi ganda.

\section{HASIL PENELITIAN}

\section{Deskripsi Data}

Data penelitian ini meliputi variabel self efficacy $\left(\mathrm{X}_{1}\right)$, motivasi berprestasi $\left(\mathrm{X}_{2}\right)$, prokrastinasi akademik $\left(\mathrm{X}_{3}\right)$, dan stres akademik mahasiswa (Y). Berikut adalah deskripsi hasil pengolahan data penelitian

\section{Self Efficacy $\left(\mathrm{X}_{1}\right)$}

Deskripsi data self efficacy mahasiswa yang berjumlah 236 responden dapat dilihat pada Tabel 1 .

\section{Tabel 1. Distribusi Frekuensi Berdasarkan} Kategori Skor Self Efficacy

\begin{tabular}{|c|c|c|c|}
\hline $\begin{array}{c}\text { Interval } \\
\text { Skor }\end{array}$ & Kategori & $\begin{array}{c}\text { Frekuensi } \\
(\mathrm{f})\end{array}$ & $\begin{array}{c}\text { Persentase } \\
(\%)\end{array}$ \\
\hline$\geqslant 138$ & $\begin{array}{c}\text { Sangat } \\
\text { Tinggi }\end{array}$ & 31 & 13.1 \\
\hline $111-137$ & Tinggi & 156 & 66.1 \\
\hline $84-110$ & Sedang & 48 & 20.3 \\
\hline $57-83$ & Rendah & 1 & 0.4 \\
\hline$\leqslant 56$ & $\begin{array}{c}\text { Sangat } \\
\text { Rendah }\end{array}$ & 0 & 0.0 \\
\hline Total & \multicolumn{3}{|l}{} \\
\hline
\end{tabular}

Berdasarkan Tabel 1 dapat dilihat bahwa sebagian besar mahasiswa yaitu $66,1 \%$ memiliki self efficacy tinggi, 20,3\% mahasiswa memiliki self efficacy sedang, 
13,1\% mahasiswa memiliki self efficacy sangat tinggi, dan $0,4 \%$ mahasiswa memiliki self efficacy rendah. Secara rata-rata capaian terhadap skor ideal dari variabel self efficacy adalah 73,3\%. Jadi, dapat disimpulkan bahwa secara rata-rata self efficacy mahasiswa BK FIP UNP berada pada kategori tinggi.

\section{Motivasi Berprestasi $\left(\mathrm{X}_{2}\right)$}

Deskripsi data motivasi berprestasi mahasiswa yang berjumlah 236 responden dapat dilihat pada Tabel 2 .

Tabel 2. Distribusi Frekuensi Berdasarkan

Kategori Skor Motivasi Berprestasi

\begin{tabular}{|c|c|c|c|}
\hline $\begin{array}{c}\text { Interval } \\
\text { Skor }\end{array}$ & Kategori & $\begin{array}{l}\text { Frekuensi } \\
\text { (f) }\end{array}$ & $\begin{array}{c}\text { Persentase } \\
(\%)\end{array}$ \\
\hline$\geq 189$ & $\begin{array}{l}\text { Sangat } \\
\text { Tinggi }\end{array}$ & 13 & 5,5 \\
\hline $153-188$ & Tinggi & 119 & 50,4 \\
\hline $117-152$ & Sedang & 103 & 43,6 \\
\hline $81-116$ & Rendah & 1 & 0,4 \\
\hline$\leq 80$ & $\begin{array}{l}\text { Sangat } \\
\text { Rendah }\end{array}$ & 0 & 0,0 \\
\hline \multicolumn{2}{|c|}{ Total } & 236 & $100 \%$ \\
\hline
\end{tabular}

Berdasarkan Tabel 2 dapat dilihat bahwa sebagian besar mahasiswa yaitu 50,4\%, memiliki motivasi berprestasi tinggi, 43,6\% mahasiswa memiliki motivasi berprestasi sedang, 5,5\% mahasiswa memiliki motivasi berprestasi sangat tinggi, dan $0,4 \%$ mahasiswa memiliki motivasi berprestasi rendah. Secara rata-rata capaian terhadap skor ideal dari variabel motivasi berprestasi adalah $70,18 \%$. Jadi, dapat disimpulkan bahwa secara rata-rata motivasi berprestasi mahasiswa BK FIP UNP berada pada kategori tinggi.

\section{Prokrastinasi Akademik $\left(\mathrm{X}_{3}\right)$}

Deskripsi data prokrastinasi akademik mahasiswa yang berjumlah 236 responden dapat dilihat pada Tabel 3.

Tabel 3. Distribusi Frekuensi Berdasarkan Kategori Skor Prokrastinasi Akademik

\begin{tabular}{|c|c|c|c|}
\hline $\begin{array}{c}\text { Interval } \\
\text { Skor }\end{array}$ & Kategori & $\begin{array}{l}\text { Frekuensi } \\
\text { (f) }\end{array}$ & $\begin{array}{c}\text { Persentase } \\
(\%)\end{array}$ \\
\hline$\geq 142$ & Sangat Tinggi & 2 & 0.8 \\
\hline $114-141$ & Tinggi & 57 & 24.2 \\
\hline $86-113$ & Sedang & 105 & 44.5 \\
\hline $58-85$ & Rendah & 66 & 28.0 \\
\hline$\leq 57$ & Sangat Rendah & 6 & 2.5 \\
\hline \multicolumn{2}{|r|}{ Total } & 236 & 100 \\
\hline
\end{tabular}

Berdasarkan Tabel 3 dapat dilihat bahwa sebagian besar mahasiswa yakni $51,3 \%$ memiliki prokrastinasi akademik sedang, 22,9\% mahasiswa memiliki prokrastinasi akademik tinggi, 21,6\% mahasiswa memiliki prokrastinasi akademik rendah, 2,5\% mahasiswa memiliki prokrastinasi akademik sangat tinggi dan 1,7\% mahasiswa memiliki prokrastinasi akademik sangat rendah. Secara rata-rata capaian terhadap skor ideal dari variabel self efficacy adalah 56,6\%. Jadi, dapat disimpulkan bahwa secara rata-rata prokrastinasi akademik mahasiswa BK FIP UNP berada pada kategori sedang.

\section{Stres Akademik (Y)}

Deskripsi data stres akademik yang berjumlah 236 responden dapat dilihat pada Tabel 4. Tabel 4. Distribusi Frekuensi Berdasarkan

\begin{tabular}{|c|c|c|c|}
\hline $\begin{array}{c}\text { Interval } \\
\text { Skor }\end{array}$ & Kategori & $\begin{array}{l}\text { Frekuensi } \\
\text { (f) }\end{array}$ & $\begin{array}{c}\text { Persentase } \\
(\%)\end{array}$ \\
\hline$\geqslant 126$ & $\begin{array}{l}\text { Sangat } \\
\text { Tinggi }\end{array}$ & 6 & 2.5 \\
\hline $102-125$ & Tinggi & 54 & 22.9 \\
\hline $78-101$ & Sedang & 121 & 51.3 \\
\hline $54-77$ & Rendah & 51 & 21.6 \\
\hline$\leqslant 53$ & $\begin{array}{l}\text { Sangat } \\
\text { Rendah }\end{array}$ & 4 & 1.7 \\
\hline \multicolumn{2}{|c|}{ Total } & 236 & 100 \\
\hline
\end{tabular}

\section{Kategori Skor Stres Akademik Mahasiswa}

Berdasarkan Tabel 4 dapat dilihat bahwa sebagian besar mahasiswa yakni 44,5\% memiliki stres akademik sedang, 24,2\% mahasiswa memiliki stres akademik tinggi, $28 \%$ mahasiswa memiliki stres akademik rendah, 0,8\% mahasiswa memiliki stres akademik sangat tinggi dan 2,5\% mahasiswa memiliki stres akademik sangat rendah. Secara rata-rata capaian terhadap skor ideal dari stres akademik mahasiswa adalah 61,7\%. Jadi, dapat disimpulkan bahwa secara rata-rata stres akademik mahasiswa BK FIP UNP berada pada kategori sedang.

\section{Pengujian Persyaratan Analisis Data}

Uji persyaratan analisis yang dilakukan pada data penelitian ini adalah uji normalitas, uji linieritas, dan uji multikolinieritas.

1. Uji Normalitas

Pengujian normalitas dilakukan dengan menggunakan metode Kolmogorov-Smirnov dengan taraf signifikansi > 0,5 , yang berarti bahwa data berdistribusi normal.

Berdasarkan hasil dari uji normalitas data self efficacy dengan nilai Asymp. Sig 0,661 >0,05, motivasi berprestasi dengan nilai Asymp. Sig 0,328>0,05, prokrastinasi akademik dengan nilai Asymp. Sig 0,898 > 0,05 dan stres akademik dengan nilai Asymp. Sig 0,615 > 0,05 , sehingga keempat variabel berdistribusi normal.

\section{Uji Linieritas}

Uji linieritas dalam penelitian ini memanfaatkan program SPSS versi 17.00 dengan melihat nilai linear term pada taraf signifikansi 0,05. Menurut Coakes, Steed \& Ong (2010:114) jika nilai sig. $\leq 0,05$ maka dinyatakan linier, dan jika nilai sig. > dari 0,05 maka tidak linier.

Berdasarkan hasil uji linieritas, didapatkan hasil bahwa hubungan self efficacy dengan stres akademik dikatakan linier dengan Liniear Term 0,000 < dari 0,05. Data hubungan motivasi berprestasi dengan stres akademik dinyatakan linier dengan Liniear Term 0,000 < dari 0,05 . Selanjutnya, hubungan prokrastinasi akademik dengan stres akademik dinyatakan linier dengan Liniear Term $0,000<$ dari 0,05 .

\section{Uji Multikolinieritas}

Berdasarkan nilai VIF self efficacy sebesar 1.424 motivasi berprestasi sebesar 1.850, dan stres akademik 
sebesar 1.531. Dengan demikian ketiga VIF lebih kecil dari 10. Artinya, tidak terjadi multikolinieritas antara self efficacy, motivasi berprestasi, dengan prokrastinasi akademik.

Hubungan Self Efficacy, Motivasi Berprestasi dan Prokrastinasi Akademik dengan Stres Akademik Mahasiswa

\section{Hubungan Self Efficacy dengan Stres Akademik} Mahasiswa

Hasil analisis hubungan self efficacy dengan stres akademik sebagaimana dilihat pada Tabel 5.

Tabel 5. Hasil Analisis Regresi Linier

Sederhana dan Uji Signifikansi $\mathrm{X}_{1}$ dengan $\mathbf{Y}$

\begin{tabular}{|l|l|l|}
\hline Variabel & R & R Square \\
\hline $\mathrm{X}_{1}-\mathrm{Y}$ & .300 & .090 \\
\hline
\end{tabular}

Pada Tabel 5 dapat dilihat bahwa nilai R sebesar 0,300 yang menunjukkan koefisien regresi antara self efficacy dengan stres akademik. Nilai $R$ Square $\left(R^{2}\right)$ sebesar 0,090, ini berarti $9 \%$ variasi pada stres akademik mahasiswa dapat dijelaskan oleh self efficacy, sedangkan sisanya $91 \%$ dijelaskan oleh variabel lain. Arah hubungan self efficacy dengan stres akademik berkorelasi negatif.

2. Hubungan Motivasi Berprestasi dengan Stres Akademik Mahasiswa

Hasil analisis hubungan motivasi berprestasi dengan stres akademik mahasiswa sebagaimana dilihat pada Tabel 6.

Tabel 6. Hasil Analisis Regresi Linier Sederhana dan Uji Signifikansi $\mathrm{X}_{2}$ dengan $\mathbf{Y}$

dengan Y
\begin{tabular}{|l|l|l|}
\hline Variabel & R & R Square \\
\hline $\mathrm{X}_{2}-\mathrm{Y}$ & .376 & .141 \\
\hline
\end{tabular}

Pada Tabel 6 dapat dilihat bahwa nilai R sebesar 0,376 yang menunjukkan koefisien regresi antara motivasi berprestasi dengan stres akademik. Nilai R Square $\left(\mathrm{R}^{2}\right)$ sebesar 0,141, ini berarti $14,1 \%$ variasi pada stres akademik mahasiswa dapat dijelaskan oleh motivasi berprestasi, sedangkan sisanya $85,9 \%$ dijelaskan oleh variabel lain. Arah hubungan motivasi berprestasi dengan stres akademik berkorelasi negatif.

3. Hubungan Prokrastinasi Akademik dengan Stres Akademik Mahasiswa

Hasil analisis hubungan prokrastinasi akademik dengan stres akademik mahasiswa sebagaimana dilihat pada Tabel 7 .

Tabel 7. Hasil Analisis Regresi Linier Sederhana dan Uji Signifikansi X3 dengan $Y$

\begin{tabular}{|l|l|l|}
\hline Variabel & $\mathbf{R}$ & R Square \\
\hline $\mathrm{X}_{3}-\mathrm{Y}$ & .629 & .395 \\
\hline
\end{tabular}

Pada Tabel 7 dapat dilihat bahwa nilai R sebesar 0,629 yang menunjukkan koefisien regresi antara prokrastinasi akademik dengan stres akademik akademik. Nilai $R$ Square $\left(R^{2}\right)$ sebesar 0,395 , ini berarti $39,5 \%$ variasi pada stres akademik mahasiswa dapat dijelaskan oleh prokrastinasi akademik, sedangkan sisanya $60,5 \%$ dijelaskan oleh variabel lain. Arah hubungan prokrastinasi akademik dengan stres akademik berkorelasi positif.

4. Hubungan Self efficacy, Motivasi Berprestasi dan Prokrastinasi Akademik dengan Stres Akademik Mahasiswa

Hasil analisis hubungan self efficacy, motivasi berprestasi, dan prokrastinasi akademik dengan stres akademik mahasiswa sebagaimana dilihat pada Tabel 8 .

Tabel 8. Hasil Analisis Regresi Ganda dan Uji Signifikansi $X_{1}, X_{2}$, dengan $Y$

\begin{tabular}{|l|l|l|}
\hline Variabel & $\mathbf{R}$ & R Square \\
\hline $\mathrm{X}_{1} \mathrm{X}_{2} \mathrm{X}_{3}-\mathrm{Y}$ & .633 & .400 \\
\hline
\end{tabular}

Pada Tabel 8 dapat dilihat bahwa nilai R sebesar 0,633 yang menunjukkan koefisien regresi ganda antara self efficacy, motivasi berprestasi, dan prokrastinasi akademik dengan stres akademik mahasiswa. Nilai $R$ Square $\left(R^{2}\right)$ sebesar 0,400 , ini berarti $40 \%$ variasi pada stres akademik dapat dijelaskan secara bersama-sama oleh self efficacy, motivasi berprestasi, dan prokrastinasi akademik, sedangkan sisanya $60 \%$ dijelaskan oleh variabel lain.

\section{PEMBAHASAN}

\section{Self Efficacy Mahasiswa BK FIP UNP}

Temuan penelitian menunjukkan bahwa self efficacy mahasiswa BK FIP UNP secara keseluruhan berada pada kategori tinggi. Tingginya self efficacy mahasiswa menunjukan bahwa mahasiswa telah memiliki tingkat keyakinan yang kuat akan kemampuannya dalam menjalankan tugasnya sebagai mahasiswa seperti belajar, penyelesaian tugas, dan memanfaatkan lingkungan belajar. Hal ini menunjukan kemampuan mahasiswa dalam berbagai aspek yang mempengaruhi pembelajaran mereka sebagai mahasiswa dapat diatasi dengan keyakinan diri yang kuat dari diri mahasiswa tersebut.

Bandura (1997:3) menyatakan "Self efficacy refers to beliefs in one's capability to organize and execute the courses of action required to produce given attainments". Dari definisi yang dirumuskan Bandura, dapat dipahami bahwa self efficacy merupakan keyakinan seseorang akan kemampuannya untuk mengatur dan melaksanakan serangkaian tindakan yang dibutuhkan untuk menghasilkan hasil yang ingin dicapai.

Self efficacy merupakan keyakinan dan harapan mengenai kemampuan mahasiswa untuk mengahadapi tugasnya. Untung (2008:30) menyatakan bahwa berbagai studi menunjukkan self efficacy berpengaruh terhadap keinginan, keuletan dalam menghadapi kesulitan dari suatu tugas, dan dalam meningkatkan prestasi belajar. Dengan demikian, mahasiswa yang memiliki self efficacy yang rendah merasa tidak memiliki keyakinan bahwa mereka dapat menyelesaikan tugas dengan baik, maka mahasiswa tersebut akan berusaha untuk menghindari tugas tersebut. Self efficacy yang rendah tidak hanya dialami oleh mahasiswa yang tidak memiliki kemampuan untuk belajar, tetapi memungkinkan dialami juga oleh 
mahasiswa berbakat yang tidak memiliki keyakinan akan kemampuan dari dirinya.

Dengan demikian dapat di simpulkan bahwa self efficacy yang kuat akan dapat mempengaruhi proses pembelajaran mahasiswa di lingkungan pendidikannya. Kemudian, self efficacy sangat perlu ditingkatkan untuk mencapai pendidikan yang merata dalam proses pembelajaran mahasiswa. Pengembangan dan peningkatan self efficacy mahasiswa tidak hanya dapat dilakukan oleh individu itu sendiri namun sangat dibutuhkan dorongan atau dukungan dari stake holder di ranah pendidikan mahasiswa yaitu dalam lingkungan kampus dan lingkungan pendukung lainnya.

\section{Motivasi Berprestasi Mahasiswa BK FIP UNP}

Temuan penelitian memperlihatkan bahwa motivasi berprestasi mahasiswa BK FIP UNP secara keseluruhan berada pada kategori tinggi. Hal ini mengambarkan bahwa mahasiswa BK FIP UNP memiliki motivasi berprestasi yang kuat dan tinggi dalam pelaksanaan tugas belajarnya sebagai mahasiswa yang dapat dilihat dengan kemampuannya dalam meningkatkan motivasi berprestasinya.

Motivasi berprestasi merupakan daya penggerak yang mendorong dan memotivasi semangat seseorang, untuk mengembangkan kemampuannya dalam mencapai prestasi yang maksimal dan menggerakkan semua kemampuan/energi yang dimilikinya demi mencapai prestasi yang maksimal (Santrock, 2003:475). Dorongan itu dapat berasal dari dalam diri individu/instrinsik ataupun dorongan yang berasal dari luardiri individu/ekstrinsik, individu mamanfaatkan dorongan ini untuk mencoba mencapai hasil yang lebih maksimal dalam pembelajarannya sebgai mahasiswa.

Heckhausen (dalam Diniati, 2001:18) menambahkan bahwa motivasi berprestasi sebagai usaha keras individu untuk meningkatkan atau mempertahankan kecakapan diri setinggi mungkin dalam semua aktivitas dengan menggunakan standar keunggulan sebagai pembanding. Standar keunggulan yang dimaksud adalah berupa prestasi orang lain atau prestasi sendiri yang pernah diraih sebelumnya. Dalam hal ini motivasi berprestasi mahasiswa BK meningkat salah satunya dengan asepk pendukungnya seperti kesemmpatan untuk unggul dari orang lain.

Mahasiswa yang memiliki motivasi berprestasi yang tinggi akan mengerjakan sesuatu secara optimal karena mengharapkan hasil yang lebih baik dari standar yang ada. Adanya motivasi berprestasi, membuat seseorang mengerahkan seluruh kemampuannya untuk menjalankan kegiatan belajarnya semaksiamal mungkin, semua kegiatan yang sudah menjadi tugas dan tanggung jawabnya untuk mencapai target-target tertentu yang harus dicapainya pada setiap satuan waktu dengan penuh semngat dan orientasi yang kuat untuk berhasil. Mahasiswa tersebut menyukai tugas-tugas yang menantang tanggung jawab secara pribadi dan terbuka untuk umpan balik guna memperbaiki prestasi inovatif kreatifnya.

Berdasarkan hasil analisis deskriptif menunjukan bahwa motivasi berprestasi mahasiswa BK FIP UNP berada pada kategori tinggi. Namun, peningkatan motivasi berprestasi juga perlu terus dilanjuttkan dan dikembangkan pada setiap mahasiswa. Dengan peningkatan yang terus dilaksanakan diharapkan kedepannya pendidikan Indonesia dapat mencapat hasil yang optimal dan pendidikan akan terasa menyenangkan dengan mahasiswa yang bermotivasi berprestasi yang tinggi ini.

\section{Prokrastinasi Akademik Mahasiswa BK FIP UNP}

1. Temuan penelitian memperlihatkan bahwa perilaku prokrastinasi akademik pada mahasiswa BK FIP UNP berada pada kategori sedang. Prokrastinasi merupakan sebuah bentuk perilaku yang menunda dalam pengerjaan suatu aktivitas (Mayasari, 2010:97). Perilaku menunda ini merupakan akibat dari kesalahan dalam berpikir dan adanya pikiran-pikiran yang irasional terhadap tugas seperti takut gagal dalam penyelesaian suatu tugas atau pekerjaan invidu dalam sehari-harinya.

2. Adapun dalam penelitian ini prokrastinasi yang di bahas adalah prokrastinasi atau penundaan yang sering terjadi pada mahasiswa dalam pembelajarannya atau lebih dikenal dengan prokrastinasi akademik. Rumiani (2006:38) menjelaskan bahwa prokrastinasi akademik merupakan suatu perilaku menunda-nunda pengerjaan tugas yang terjadi dalam lingkungan akademik. Penundaan dalam pegerjaan tugas akademik jeals memberikan berbagai dampak dalam pelaksaan pendidikan di lingkungan kampus terutama dampak negatif yang sangat merugikan mahasiswa.

3. Seseorang yang melakukan prokrastinasi terkadang tidak bermaksud untuk menghindari atau tidak mau tahu dengan tugas yang dihadapinya. Akan tetapi, mahasiswa tersebut hanya menunda-nunda untuk mengerjakannya sehingga menyita waktu dalam pengerjaan tugastugas tersebut dan hasil maksiamal dan optimal yang di harapakan sebelumnya tidak dapat diraih dengan baik.

4. Dalam penelitian ini menggali tentang perilaku prokrastinasi akademik mahasiswa BK FIP UNP terutama dalam aspek-aspekyang menjadi pendukung dalam pelaksanaan penlitian ini. Aspek-aspek itu berupa tugas menulis sebagai seorang mahasiswa, tugas belajar menghadapi ujian, prokrastinasi mahasiswa, tugas membaca, tugas administratif, dan tugas kehadiran sebagai mahasiswa.

Hal ini menunjukan bahwa mahasiswa BK FIP UNP masih banyak yang melakukan prokrastinasi dalam pengerjaan tugas-tugasnya sebagai seorang mahasiswa. Oleh karena itu hal ini tidak boleh larut dengan kebiasaan prokrastinasi ini maka diperlukan dorongan terhadap mahasiswa yang biasa jadi procrastinator agar tidak terus berada pada kondisi yang demikian sehingga prokrasiasi akademik yang di alami mahasiswa BK FIP UNP dapat di 
turunkan menjadi rendah bahkan tidak ada lagi mahasiswa yang melakukan prokrastinasi.

\section{Stres Akademik Mahasiswa BK FIP UNP}

1. Hasil temuan mengambarkan bahwa stres akademik mahasiswa BK FIP UNP tergolong pada kategori sedang. Hal ini menunjukan bahwa masih ada kemungkinan stres akademik mahasiswa BK FIP UNP akan meningkat atau sebaliknya akan menurun. Stres merupakan suatu bentuk interaksi antara mahasiswa dengan lingkungan yang dinilai mahasiswa sebagai sesuatu yang membebani atau melampaui kemampuan yang dimilikinya serta dianggap dapat mengancam kehidupan efektif sehari-harinya (KES).

2. Interaksi mahasiswa dengan lingkungan kampus adalah interaksi edukatif, yakni interaksi yang mengarah kepada pencapaian prestasi belajar, bukan pada pencapaian prestasi kerja. Karena itu, stres yang dialami siswa lebih merupakan stres belajar. Oleh sebab itu, para peneliti berusaha mengembangkan sebuah konsep secara khusus menggambarkan kondisi stres yang dialami oleh siswa akibat tuntutan sekolahnya, yakni academic stress.

Gusniarti (dalam Eryanti, 2002:17) mengemukakan stres akademik yang dialami siswa merupakan persepsi yang subjektif terhadap adanya ketidaksesuaian antara tuntutan lingkungan akademis dan sumber daya aktual yang dimiliki mahasiswa sebagai seorang mahasiswa sebagai seorang sasaran pendidikan. Hal ini dapat berpengaruh terhadap kondisi diri mahasiswa itu sendiri dimana keseimbangan yang di harapkan antara lingkungan dan sumber daya yang di harapkan tidak dapat diraih oleh mahasiswa dalam kondisi normal.

Gejala-gejala stres akademik yang dibahas dalam penelitian ini gejala/respon yang menyebabkan stres akademik pada mahasiswa BK FIP UNP yaitu: (1) respon fisik, (2) respon emosi, dan (3)respon perilaku. Dari ketiga respon penyebab stres akademik ini masih besar kemungkinan stres akademik pada mahasiswa BK ini akan meningkat karena perilaku inidividu yang tidak mampu mengambil sebuah sikap atau keputusan yang tepat dalam menghadapi sesuatu permasalahan. Untuk itu diharapkan berbagai metode pembelajaran yang dapat mendukung mahasiswa untuk dapat berfikir secara logis dan tidak ada di bawah tekanan sehingga tidak terjadi stres akademik pada mahasiswa tersebut.

\section{Hubungan Self Efficacy dengan Stres akademik Mahasiswa}

Berdasarkan temuan penelitian memperlihatkan terdapat hubungan negatif dan signifikan antara self efficacy dengan stres akademik mahasiswa. Temuan ini dapat mendukung temuan sebelumnya oleh Pratiwi (2012) dalam penelitiannya terhadap mahasiswa BK UNY menemukan terdapat hubungan negatif antara self efficacy dengan stres akademik mahasiswa. Penelitian ini mengemukakan bahwa semakin tinggi self efficacy mahasiswa maka semakin rendah tingkat stres mahasiswa, begitupun sebaliknya semakin rendah self efficacy mahasiswa, maka semakin tinggi tingkat stres akademiknya.

Berdasarkan temuan tersebut terlihat bahwa keyakinan seorang mahasiswa dapat mempengaruhi aspek kepribadiannya yang lain seperti stres yang timbul pada diri mahasiswa. Self Efficacy berperan penting dalam menghadapi kondisi stres yang dihadapi mahasiswa. Mahasiswa yang memilliki self efficacy yang kuat, terbukti mengalami tekanan yang lebih rendah saat berhadapan dengan sumber stres atau stressor. Jadi, apabila mahasiswa memiliki self efficacy yang kuat, maka ia akan kuat dan tangguh dalam menghadapi stres.

Dalam hal ini dikaitkan dengan self efficacy mahasiswa yang rendah cenderung akan bersifat malas, cemas dan tidak percaya diri dalam pegerjaan tugasnya sehingga mahasiswa cenderung mengalami stres akademik. Akibatnya mahasiswa menjadi tertekan, cemas, dan tidak percaya diri atas penyelesaian tugas tersebut. Dengan demikian sangat di perlukan peranan dari self efficacy dalam mencegah terjadinya hal tersebut. Self efficacy adalah aspek kepribadian yang muncul dari dalam diri mahasiswa atau bersifat internal, stres akademik akan dapat dientaskan oleh mahasiswa jika dapat menyeimbangkan self efficacy dengan faktor-faktor yang bersifat eksternal yang bersifat positif.

\section{Hubungan Motivasi Berprestasi dengan Stres akademik}

Berdasarkan temuan penelitian memperlihatkan terdapat hubungan negatif dan signifikan antara motivasi berprestasi dengan stres akademik mahasiswa. Kebanyakan motivasi manusia dibangkitkan melalui kognitif. Individu memberi motivasi atau dorongan bagi diri mereka sendiri dan mengarahkan tindakan melalui tahap pemikiran-pemikiran sebelumnya. Motivasi berprestasi menjadi hal yang sangat penting dalam mengatasi dan mencegah terjadinya suatu kegagagalan tersebut. Dimana seorang mahasiswa yang memiliki motivasi berprestasi yang tinggi akan cenderung berusaha untuk memanajemen waktunya dengan baik dalam menentukan suatu tujuan yang telah di tetapkan sebelumnya sehingga kegagalan yang kan terjadi dapat di minimalisir oleh mahasiswa tersebut.

Mahasiswa yang memiliki motivasi berprestasi yang tinggi tidak akan mau membuang waktunya dengan beralih kepada hal-hal yang tidak berguna dalam mengerjakan tugasnya dengan baik dan maksimal sehingga dia merasa tidak ada beban serta tekanan dalam penyelesaian tugasnya. Namun sebaliknya mahasiswa yang memiliki motivasi berprestasi yang rendah akan cenderung merasa terbebani dengan tugas yang dihadapinya sehingga sering memaksakan diri untuk mengerjakannya melebihi batas kemampuannya sehingga menimbulkan stres pada diri mahasiswa tersebut.

Dengan demikian dapat disimpulkan bahwa terdapat hubungan negatif antara motivasi berprestasi dengan stres akademik mahasiswa BK FIP UNP. Dimana semakin tinggi motivasi berprestasi mahasiswa maka semakin rendah stres akademik pada diri mahasiswa tersebut. Sebaliknya, semakin rendah motivasi berprestasi berprestasi mahasiswa dalam melaksanakan proses 
pendidikan maka stres akademik akan meningkat karena adanya tujuan dari pembelajaran yang tidak dapat di capai dengan baik.

\section{Hubungan Prokrastinasi Akademik dengan Stres Akademik Mahasiswa}

Berdasarkan temuan penelitian memperlihatkan terdapat hubungan positif dan signifikan antara prokrastinasi akademik dengan stres akademik mahasiswa. Prokrastinasi akademik menimbulkan berbagai dampak negatif dalam kegiatan akademik mahasiswa. Widyawati dan Asih (dalam anggawijaya, 2013) mengemukakan bahwa prokrastinasi akan menimbulkan kecemasan pada diri mahasiswa, kecemasaan yang berlebihan akan menimbulkan stres akademik yang berkelanjutan bahkan mencapai depresi sehingga menyebabkan terganggunya kehidupan efektif mahasiswa tersebut.

Kemudian, tugas yang banyak dalam perkuliahan dan dibiarkan menumpuk akan membuat prokrastinator menjadi malas dan tidak tertarik untuk melakukannya. Hal ini juga akan menimbulkan tekanan dalam diri mahasiswa saat tugas harus diselesaikan dengan waktu yang singkat. Santrock (2008:235) menyatakan bahwa alasan peserta didik melakukan prokrastinasi akademik meliputi manajemen waktu yang buruk, kesulitan untuk berkonsentrasi, merasa takut dan kecemasan (sebagai contoh rasa bosan dengan tugas dan takut mendapat nilai buruk), keyakinan negatif (sebagai contoh saya tidak akan berhasil pada apapun), masalah pribadi, kebosanan, espektasi yang tidak realistik, dan perfeksionisme serta ketakutan terhadap kegagalan.

Prokrastinasi akademik diduga dapat mempengaruhi keberhasilan akademik dan pribadi mahasiswa BK FIP UNP. Apabila kebiasaan menunda ini muncul terusmenerus pada mahasiswa, tentu akan memberikan dampak negatif dalam kehidupan akademik mahasiswa itu sendiri seperti: nilai tidak memenuhi standar, gagal dalam ujian, tertunda dalam penyelesaian tugas akhir, penyelesaian skripsi, dan lain sebagainya. Hal inilah yang berdampak pada stres akademik mahasiswa akan semakin meningkat juga begitu sebaliknya. Dengan demikian dapat dilihat hubungan positif antara prokrastinasi akademik dengan stres akademik mahasiswa.

8. Hubungan antara Self Efficacy, Motivasi Berprestasi dan Prokrastinasi Akademik dengan Stres Akademik

Berdasarkan hasil analisis data yang telah dilakukan memperlihatkan bahwa terdapat hubungan yang signifikan antara self efficacy, motivasi berprestasi, prokrastinasi akademik dengan stres akademik mahasiswa dengan koefisien regresi 0.623 dan $\mathrm{R}^{2} 0.380$. Namun jika dilihat dari hasil uji signifikansi regresi ganda ternyata tidak terdapat hubungan yang signifikan antara self efficacy dan motivasi berprestasi, dengan stres akademik mahasiswa. Sedangkan untuk variabel prokrastinasi akademik terdapat hubungan yang signifikan.

Hilangnya makna hubungan variabel self efficacy dan prokrastinasi motivasi berprestasi dengan stres akademik mahasiswa karena ditekan oleh hubungan prokrastinasi akademik dengan stres akademik mahasiswa. Berdasarkan nilai $\mathrm{R}^{2}$ artinya stres akademik dipengaruhi oleh $38 \%$ self efficacy, motivasi berprestasi dan prokrastinasi akademik, dan $62 \%$ lagi berkemungkinan dipengaruhi oleh faktor lain yang belum dijelaskan dalam penelitian ini. Hal ini terlihat bahwa self efficacy, motivasi berprestasi dan prokrastinasi akademik secara bersama-sama lumayan dapat mempengaruhi stres akademik, diduga ada faktor lain yang dapat mempengaruhi stres akademik mahasiswa.

Untuk mendukung temuan ini sama seperti yang pendapat Oon (2007:36) yang telah di jelaskan pada Bab 2 tentang faktor penyebab stres akademik yaitu pola pikir individu, kepribadian, kebiasaan menunda-nunda tugas, keyakinan diri (self efficacy), jam pelajaran yang padat, tekanan atau dorongan berprestasi dan dorongan orangtua. Dengan demikian dapat dilihat hubungan yang kuat antara variabel $\mathrm{X}$ dangan variabel $\mathrm{Y}$.

Rathus (dalam Irza, 2007) mengemukakan bahwa orang stres cenderung mengaitkan segala sesuatu dengan dirinya. Pada tingkat stres yang tinggi, orang bisa menjadi depresi, kehilangan rasa percaya diri, keyakinan diri dan harga diri. Akibatnya dia lebih banyak menarik diri dari lingkungannya, suka menyendiri, dan tidak tertarik melakukan pekerjaan yang seharusnya dilakukannya. Begitu juga dengan mahasiswa ketika berada pada kondisi stres akademik yang tinggi mahasiswa akan kesulitan mengontrol dirinya dan mengembalikan keyakinan dirinya dalam pengerjaan tugas akademiknya, dia akan cendrung mengindahkan untuk mengerjakan tugas karena motivasi berprestasinya tidak ada, akibatnya mahasiswa melakukan prokrastinasi dan terus berada dalam tekanan. Dengan demikian, dapat disimpulkan terdapat hubungan antara variabel self efficacy $\left(\mathrm{X}_{1}\right)$, motivasi berprestasi $\left(\mathrm{X}_{2}\right)$, prokrastinasi akademik $\left(\mathrm{X}_{3}\right)$, dan juga stres akademik mahasiswa (Y) baik antar masing-masing variabel maupun secara bersama.

\section{KESIMPULAN}

Temuan hasil penelitian, dapat dikemukakan simpulan sebagai berikut.

1. Secara umum gambaran self efficacy dan motivasi berprestasi mahasiswa BK FIP UNP berada pada kategori tinggi, sedangkan prokrastinasi akademik dan stres akademiknya berada pada kategori sedang.

2. Terdapat hubungan yang negatif dan signifikan antara self efficacy dengan stres akademik mahasiswa BK FIP UNP.

3. Terdapat hubungan yang negatif dan signifikan antara motivasi berprestasi dengan stres akademik mahasiswa BK FIP UNP.

4. Terdapat hubungan yang positif dan signifikan antara prokrastinasi akademik dengan stres akademik mahasiswa BK FIP UNP.

5. Terdapat hubungan yang signifikan antara self efficacy, motivasi berprestasi, dan prokrastinasi akademik dengan stres akademik mahasiswa BK FIP UNP secara bersamaan. 


\section{SARAN}

Berdasarkan hasil penelitian, pembahasan, simpulan, dan implikasinya ada kesempatan dalam meningkatkan self efficacy dan motivasi berprestasi pada mahasiswa, serta mengurangi/mencegah terjadinya prokrastinasi dan stres akademik mahasiswa.

Kepada dosen diharapkan mampu melihat berbagai permasalahan yang ada pada mahasiswa, terutama yang berhubungan dengan variabel yang diteliti dalam penelitian ini dan juga faktor lain yang menjadi mahasiswa tidak dapat belajar dengan baik. Dosen juga dapat melaksanakan dan meningkatkan pelaksanaan layanan dalam pembelajaran. Layanan ini berkaitan dengan peningkatan self efficacy mahasiswa dan motivasi berprestasi mahasiswa BK FIP UNP menjadi lebih baik lagi. Kemudian, layanan yang dapat di berikan kepada mahasiswa yang berhubungan dengan pengentasan perilaku prokrastinasi akademik mahasiswa dan penyebab timbulnya stres akademik pada mahasiswa BK FIP UNP.

Dosen Pembimbing Akademik (PA) juga diharapkan dapat memberi perhatian kepada mahasiswa bimbingannya terutama dalam permasalahan yang berhubungan dengan pribadi mahasiswa dan juga permasalahan dalam penyelesaian tugas akademik mahasiswa, agar tidak ada lagi pandangan negatif pada mahasiswa seperti: mahasiswa abadi, tua kampus, koboi kampus, dan sebagainya. Karena pandangan tersebut hanya akan memberikan dampak negatif juga kepada mahasiswa yang dapat menyebabkan mahasiswa melakukan prokrastinasi dan dapat menimbulkan stres akademik. Perhatian, arahan dan bimbingan dari dosen PA diharapkan mampu meningkatkan self efficacy dan motivasi berprestasi mahasiswa bimbingannya.

Unit Pelayanan Bimbingan dan Konseling (UPBK) UNP selaku lembaga yang melaksanakan kegiatan layanan bimbingan dan konseling di UNP, diharapkan dapat melaksanakan layanan bimbingan dan konseling di lingkungan kampus secara terprogram. Kemudian UPBK mampu menjalin kerjasama dengan dosen pembina mata kuliah dan dosen pembimbing akademik dalam pengentasan permasalahan mahasiswa yang berhubungan dengan prokrastinasi akademik dan stres akademik yang tinggi serta motivasi berprestasi dan self efficacy mahasiswa yang menurun serta permasalahan lainnya yang dapat mengganggu proses belajar mahasiswa.

Kepada mahasiswa diharapkan mampu meningkatkan self efficacy dan motivasi berprestasi dalam dirinya dengan mencegah adanya prokrastinasi akademik, stres akademik, serta gangguan lainnya yang dapat mengganggu dalam pencapaian hasil belajar yang maksimal dan dapat menyelesaikan perkuliahan tepat waktu. Mahasiswa juga diharapkan mampu membina komunikasi yang baik dengan dosen-dosen pembina mata kuliah ketika menghadapi permasalahan yang dapat mengganggu pembelajaran, sehingga dosen dapat membantu dalam pengentasan permasalahan tersebut.

\section{DAFTAR PUSTAKA}

As'ari, D. K. 2007. Mengenal Mahasiswa dan Seputar Organisasinya. Jakarta: Pena Deni.

Diniaty, A. 2001. "Keikutsertaan Siswa pada Lembaga Bimbingan Belajar dalam Kaitannya dengan Motivasi Berprestasi, Kemampuan dan Masalah Belajar serta Peran Guru Pembimbing di SMUN 1 Padang”. Tesis tidak diterbitkan. Padang: Program Pascasarjana Universitas Negeri Padang.

Eryanti, F. 2012. "Perbedaan Stres Akademik antara Kelompok Siswa Minoritas dengan Mayoritas di SMP WR. Supratman 2 Medan". Jurnal USU, (Online), Vol. 7, No. 6, (145-162) http://www.Jurnal.usu.ac.id/index.php/, diakses September 2014.

Hasibuan, M. 2005. Organisasi dan Motivasi Dasar Peningkatan Produktivitas. Jakarta: Raja Grafindo Persada.

Irza, A. I. 2007. "Persepsi atas Program Akselerasi dan Stres Akademik". Jurnal Proviate. Jakarta: Fakutas Psikologi Universitas Tarumanegara. Vol. 3, No. 1, (http://www.journal.tarumanagara.ac.id/, diakses Oktober 2014)

Mayasari, M. D. 2010. "Hubungan antara Persepsi Mahasiswa terhadap Metode Pengajaran Dosen dengan Kecenderungan Prokrastinasi Akademik pada Mahasiswa Fakultas Psikologi Universitas Hang Tuah Surabaya”. Jurnal INSAN. Vol. 12, No. 02, (http://www.ejournal.unair.ac.id/edu, diakses September 20140

Melisa. 2012. "Hubungan Tingkat Stress dengan Perilaku Prokrastinasi Akademik pada Mahasiswa Universitas Bina Nusantara yang Sedang Mengerjakan Skripsi”. Jurnal Epsikologi, DKI Jakarta: Universitas Bina Nusantara. Vol. 2, No. 3, (23-24).

Misra, R \& McKean. 2000. College Students Academic Stress and Its Relation to Their Anxiety, Time Management, and Leisure Satisfaction. American Jurnal of Health Studies, (Online), (Http://findarticles.com/p/articles/mi, di akses Oktober 2014).

Narulita, A. 2011. "Hubungan Penyesuaian Diri, Motivasi Berprestasi dengan Stres Akademik Mahasiswa Perantauan Bandung". Karya Ilmiah Universitas Negeri Malang: Malang.

Oon, A, N. 2007. Handling Study Stress. Jakarta: Alex Media Komputindo.

Taufik, T., \& Ifdil, I. (2013). Kondisi Stres Akademik Siswa SMA Negeri di Kota Padang. Jurnal Konseling dan Pendidikan, 1(2), 143-150. 
Patricia. 2012. "Hubungan antara Distress dan Prokrastinasi Akademik Mahasiswa". Jurnal Pendidikan dan Pengajaran. Vol. 45, No. 2, (14-27).

Pratiwi, B. 2012. "Hubungan antara Keyakinan Diri (Self Efficacy) dalam Mengerjakan Skripsi dengan Stres yang dialami pada Mahasiswa Program Study BK UNY". Tesis tidak diterbitkan. Fakultas Ilmu Pendidikan: Universitas Negeri Yogyakarta.

Rizki, S. A. 2009. "Hubungan Prokrastinasi Akademis dan Kecurangan Akademis pada Mahasiswa Fakultas Psikologi Universitas Sumatera Utara”. Jurnal USU, (Online), Vol. 4, No. 2, (http://www.Jurnal.usu.ac.id/index.php/USU/search/, diakses September 2014).

Rumiani. 2006. "Prokrastinasi Akademik Ditinjau dari Motivasi Berprestasi dan Stres Mahasiswa". Jurnal Psikologi Universitas Diponegoro. Vol. 3, No. 2.

Santrock, J. W. 2003. Adolescence: Perkembangan remaja. Jakarta: Erlangga.

Santrock, J. W. 2008. Psikologi Pendidikan. Jakarta: Kencana.

Sarafino, E. P. 2006. Health Psychology (5nd. ed). New York. John Wiley and Sons.

$2 \quad$ Tatan, Z. M. 2012. “Analisis Prokrastinasi Tugas Akhir atau Skripsi”. Prosiding. ISBN : 978-979-16353-87.

Untung, M. 2008. "Pengaruh Self-Efficacy terhadap Resiliensi pada Mahasiswa Fakultas Psikologi Universitas Islam Negeri (UIN)". Jurnal psikologi 